\title{
Research on Moral Education Methods for Ethnic Preppies
}

\author{
Jian Hang \\ School for Nationalities \\ Huanghe Science and Technology College \\ Zhengzhou, China
}

\begin{abstract}
The moral education during preparatory education is to correctly guide the ideology of students and train high quality preppies. It inherits traditional Chinese culture and strengthens the identification of ethnic preppies for Chinese culture. We research how to achieve the effect through such means as the moral education perception and rational sublimation supported by discipline competition, the moral education of teachers purposed for a personal example as well as the other moral education assisted by student management.
\end{abstract}

\section{Keywords—national preppies; moral education; method}

\section{INTRODUCTION}

Education is to transfer the knowledge. More important, it inherits and sublimates humanistic spirit. Teachers bear more humanistic significance. The priority among priorities of higher education is to improve the ideological and political quality of students. The preparatory education in universities embodies the ethnic policy in higher education. It is an education preferential policy provided for national minority to promote the sustainable and healthy development of economy and culture in remote ethnic areas. We research how to make the moral education during preparatory education correctly guide students' ideology, train high quality preppies, at the meantime, inherit traditional Chinese culture and strengthen the identification of ethnic preppy for Chinese culture.

\section{MORAL EDUCATION PERCEPTION AND RATIONAL}

\section{SUBLIMATION SUPPORTED BY DISCIPLINE COMPETITION}

1. The education of "Five Outlooks (outlooks on nation, nationality, history, culture and religion)" and "Four Identifications (identifications of the great motherland, the Chinese nation, the Chinese culture and the road of socialism with Chinese characteristics)" in Marxism is long-term and important in university. It is the duty-bound responsibility of educators undertaking ideological and political theory education. Since the reform and opening-up, the party and the national departments concerned, universities and academic world have paid high attention to it. Universities serving as ethnic preparatory training base in inland are established, which has important realistic meaning. The institute for nationalities holds the activity of soliciting articles with slogan of "strengthen national unity and realize rejuvenation of the Chinese nation", to conduct the education of "Four Identifications" among students, strengthen national unity education and make students understand the deep and realistic meaning of four identifications.

2. The institute holds the activity of soliciting articles with slogan of "Preparatory Dream, Chinese Dream-Love Song" to better implement the spirit of the 18th National Congress and the publicity and education of socialism with Chinese characteristics. Publicize the party's ethnic policies and extensively carry out ideal and belief education to guide ethnic preppies to aim for the highest and fortify their ideals and convictions. Integrate preparatory dream with Chinese dream, youth dream with Chinese dream, and personal dream with national dream and firmly establish the common dream of realizing the great rejuvenation of Chinese nation. Ethnic preppies hold high the great banner of socialism with Chinese characteristics, study hard and strive to make progress in order to realize the "Chinese Dream" of national prosperity and strength, national rejuvenation and people's happiness. It fully shows ethnic preppies' spirit of loving the party, the nation and the nationality.

3. Honesty is the traditional virtue of the Chinese nation and an important reason why our Chinese people can stand in the world and receive respect. It proposes on the Third Plenary Session of 18th Central Committee of the CPC to guide students' ideology via socialist core value system and strengthen legal and honesty education. The institute for nationalities holds the activity of soliciting articles with slogan of "Honesty and Self-discipline" to let students realize the importance of honesty and self-discipline and become honest and self-disciplined in daily life.

These activities are effective method of moral education and can guide preppies' ideology correctly.

\section{MORAL EDUCATION OF TEACHERS TO TEACH BY PERSONAL EXAMPLE AS WELL AS VERBAL INSTRUCTION}

According to the characteristics of ethnic preparatory education, strengthen the publicity and education of ethnic theory and policy as well as ethnic history and culture for teachers. Carry out targeted on-the-job training for teachers to improve their ideological and political quality and professional quality, so that teachers can better teach by personal example as well as verbal instruction. Furthermore, teachers should grasp the latest information and excavate the in-depth significance contained in the latest international information 
and events, including patriotism education materials. The classroom is not closed and it cannot be closed. It is better to correctly guide rather than avoiding some sensitive questions.

\section{A. Strengthen the Construction of Teachers' Ethics}

Strongly advocate the spirit of preciseness and dedication among teachers and improve teaching level to make teachers truly become the guide in students' healthy growth. The fulltime instructors should be "strict and compassionate" to make students respect and love them. They should set a good example and "educate students with virtues, sincerity, emotion and strictness" as well as care for, understand and respect students.

\section{B. Respect Students' Ethnic Cultural Tradition and Religious Belief}

Teachers of preparatory education must have knowledge about ethnic theory and policy. Different minority groups have different cultural psychology and tradition because of the differences in geographical factors and the formation of traditional culture, especially Hui, Uyghur and Zang nationalities in the northwest and Bai, Yi, Miao and Zhuang nationalities in the southwest. The premise of ideological and political education is to understand and respect traditional culture of ethnic students. Teachers should start from ethnic customs and find specific means of ideological education so that it will improve educational efficiency and results.

Teachers should have knowledge of religion. The preparatory education follows the principle of separating religion from education. Some students are very pious for their religious belief even become obsessed. Therefore, teachers shall guide them in life and theoretical knowledge. They can tell students about the origin and nature of religion. In addition, religion is distinctly different from religion. It is easier for students to identify and helpful for their ideological education.

\section{Understand and Respect Ethnic Preppies' Individual Mental Characteristics}

In cognitive development, their abstract thinking occupies the leading position. They become more flexible and quicker but sometimes they are subjective, one-sided, stubborn and overconfident in observation and analysis of complicated social phenomenon. It needs our proper guidance and education. In emotion and will, they are full of youthful spirit, advance bravely and cherish friendship but have strong emotional fluctuation. In personality, they have strong sense of independence, self-esteem and self-confidence, but great differences exist in consciousness and stability of selfevaluation and self-education. In ideal development, most students have clear ideal and positive attitudes toward life but few students hold negative attitudes toward life and future.

Ethnic preppies have psychological and cultural tradition of their own nationality and the same characteristics as the even-aged college students of Han nationality. It needs us to understand to teach them in accordance of their aptitude.

\section{Pay Attention to Ideal and Belief Education}

Management scientist professor Luthans proposes the concept of "psychological capital" focusing on four elements namely confidence, hope, optimism and tenacity. Four elements of psychological capital are distinctly important for ethnic preppies in face of competition and perplexity. Relieve students' anxiety and tension and guide them to establish confidence so that they will envisage and treat difficulties optimistically and proceed without hesitation. In order to achieve the effect, we should guide ethnic students to reposition and highlight advantages. It is an essential to carry out the education of ideal and life belief so that we can convey qualified ethnic preppies for colleges. It is necessary to encourage and guide them to establish individual vision namely the personal ultimate goal, establish practical ideal of life and profession conforming to interests of states and nations.

\section{E. Teachers Shall Have Rich Humanistic Quality}

Schools can create and spread humanistic spirit. Teachers play a decisive and irreplaceable role in the strategic engineering. Students spend most time in school and communicating with teachers. Therefore, teachers are unique and important in humanistic quality education and building humanistic spirit. Teachers' spiritual outlook, behaviors and attitudes toward life have imperceptible influence on young students. They even become students' model. Teachers must have profound humanistic connotations to continuously train students' humanistic spirit in humanistic quality education.

\section{OTHER WAYS OF MORAL EDUCATION SUPPORTED BY STUDENT MANAGEMENT}

\section{A. Organize Military Training of Freshman Every Year to Carry out Education of Collectivism and Discipline Idea.}

The first lesson of military training for every session of preppies is to love the motherland, socialism and the core idea of the communist party of China, as well as establish the concept of be faithful to the motherland and Chinese nation. The military training teaches students to unswervingly uphold the four cardinal principles and trains their will in bearing hardships and standing hard work and the concept of obey the management.

\section{B. Organize Preppies to Visit Museums of Henan Province and Zhengzhou City and Carry out National Culture Education through Historical Relics and Sites.}

Located in the central region of the Central Plains, Zhengzhou is one of the birthplaces of Chinese culture with abundant cultural accumulation and long history. Every year after the preparatory freshmen enter school, we organize them to visit and understand the five thousand years of civilization history of Chinese nation, strengthen the sense of historical mission and cultivate national spirit.

\section{Organize Ethnic Students to Participate in Activities of Social Benefit.}

Zhengzhou is the hometown of the Yellow Emperor and holds the Memorial Ceremony to Ancestor in March 3 of lunar 
calendar every year. Our institute organizes them to wear national costume to participate. They can see the grand scene that Chinese descendants from all over the world come back home to worship and feel the national unity and the affection that blood is thicker than water.

\section{Provide Courses of Ethnic Theory and Polity to Carry out Systematic Education of Ethnic Theory and Policy.}

The professional courses can publicize the ethnic, religious and national autonomy policies of the party to make students correctly know about their nation and culture as well as other students. They can know culture is the internal impetus of national development. The ethnic development cannot separate from the inheritance of ethnic culture.

\section{E. Excellent Student Representatives Having Completed the Courses and Leading Cadres of Ethnic Areas Can Be Invited to Make Reports for Preparatory Preppies and Strengthen the Effectiveness of Ideological and Political Education.}

A fine example has boundless and credible power. Keep in touch with students having completed the courses and know about their situation, invite excellent representatives of them to introduce learning experience and the problems to which they should pay attention during the preparatory education. It helps students to adapt to undergraduate study. We also invite national cadres to use their personal experience and tell us about the support and help provided by our country for border areas and the importance of harmonious and stable political situation for the development of border areas and personal progress.

\section{F. Carry out Organization and Development and Exert the Function of Party Member, League Member and Activist of Party Application.}

We expand the access of organization and development to stimulate students' enthusiasm and select qualified students from the preppies to join the communist party of China. We transfer the membership credentials of some students who will join the $\mathrm{CPC}$ in the future to relevant schools to guarantee the continuity of training.

These efforts make ethnic preppies experience the true connotation of "ethnic minorities and the Han nationality cannot separate from each other and ethnic minorities are inseparable from each other". They can identify the nation, the nationality, culture and socialism with Chinese characteristics, meanwhile, establish correct outlook on life, values, state outlook, national concept and viewpoint on religious culture.

\section{CONCLUSION}

Under the pressure of exam-oriented education, family education and school education all emphasize intelligence instead of moral education. Many people sigh with emotion that today's adolescents are the beat generation and fail to take heavy responsibilities. The quality of moral education for adolescents concerns their growth even indirectly influences the quality of whole nation and national civilization. Therefore, moral education goes ahead of the rest in school education.
The moral education for ethnic preppy is more important. It is the important guarantee for economic and cultural development in ethnic areas to train high quality talents with integrated development.

\section{REFERENCES}

[1] The Central Committee of the Communist Party of China, the State Council. Opinions on Further Strengthening and Improving College Students' Ideological and Political Education [R], Aug.26, 2004

[2] Luo Xiaorong. Characteristics of College Students' Psychological Transformation and Countermeasures [J], Journal of Nanning Polytechnic, 2002(4)

[3] Li Shiguang. Psychological Features of Ethnic Preppy and Educational Management [J], Nationalities Research in Qinghai, 2006(3)

[4] Song Taicheng. Training Mode of Ethnic Preparatory Education and Practice [J], Heilongjiang National Series, 2005(1)

[5] Liu Xiaoyong. Research on Ideological and Political Education of Ethnic Preppies in Universities of Inner Mongolia [D], Inner Mongolia University of Science and Technology, 2001 (6)

[6] Xu Yingying. Discussion on Logical Ecology of "Five-dimension Education" in Ethnic Preparatory Education [J], Journal of Huaiyin Teachers College, 2011(4)

[7] Teng Xing, Su Hong, Multi-cultural Society and Pluralistic-integrative Education, Journal of Research on Education, 1997(1) 